\title{
Mechanical Properties of briquette by mixing rice and micrometer-sized carbon particles from potato and yam skins
}

DOI:10.36909/jer.ASSEEE.16069

Sri Anggraeni ${ }^{\mathrm{a}}$, Asep Bayu Dani Nandiyanto ${ }^{\mathrm{a}^{*},}$ Silmi Ridwan Putri ${ }^{\mathrm{a}}$, Aghisna Nuthfah Anshar ${ }^{\mathrm{a}}$, Aldi Maulana ${ }^{\mathrm{a}}$, Siti Nurazizah ${ }^{\mathrm{a}}$, Zalfa Nurjihan ${ }^{\mathrm{a}}$, Abdulkareem Sh. Mahdi Al-Obaidi ${ }^{\mathrm{b}}$

${ }^{a}$ Universitas Pendidikan Indonesia, Bandung 40154, Indonesia

${ }^{\mathrm{b}}$ School of Computer Science and Engineering, Faculty of Innovation and Technology, Taylor's University, Selangor DE, Malaysia

*Email: nandiyanto@upi.edu; Corresponding Author.

\begin{abstract}
The purpose of this study was to utilize waste potato skins (PS) and yam skins (YS) in the production of briquettes with rice waste as a binder. The basic materials used to utilize waste, especially potato skins (PS), yam skins (YS), and rice waste. Experiments were carried out by mixing and molding carbon particles made from an equal mass ratio of PS and YS with rice as binders (i.e., 10, 20, 30, 40, and 50\%). PS and YS were dried, carbonized at $250^{\circ} \mathrm{C}$ for 3 hours, and sieved to get sizes of $250 \mu \mathrm{m}$. To make compact briquettes, the molded materials were pressed with 5.66 Pa. Several characterizations were analyzed, including compressed density, relaxed density, relaxation ratio, percentage of moisture content, burning rate, percentage of water resistance index, percentage of durability index, specific fuel consumption, the puncture test, and the hardness test. The characterization results showed that the prepared briquettes have good quality, and the best was for $10 \%$ of adhesive. The best durability index was for briquettes with $30 \%$ of adhesive. The compressed density and water resistance index were optimum when
\end{abstract}


using $40 \%$ of adhesive. In general, briquettes with a low amount of adhesive have a highdensity value, low moisture content, and a long flammability. This research is expected to convey information regarding how to reuse rice waste as an adhesive for briquettes.

Keywords: rice adhesive; briquettes; potato skins; yam skins

\section{INTRODUCTION}

Briquettes are a solid material that can be burned and used as fuel to maintain a flame (C. A. Raju, et al., 2014). Many factors affect the quality of briquettes, for example the type of raw material and the amount of adhesive (A. D. Moelyaningrum, et al., 2019). Various studies on the production of briquettes with biomass-based materials have been conducted such as cotton stalks (Y. A. Abakr, et al., 2006), coconut shells (M. Yerizam, et al., 2013), water hyacinth (S. Rezania, et al., 2016), cocoa shells (H. Saptoadi, et al., 2007), as well as a mixture of teak leaves, coconut shells and rice husks briquettes (S. Syafrudin, et al., 2015). In general, briquettes are made using tapioca starch and sago adhesive.

One of the main ingredients for making briquettes is biomass (A. Amaya, et al., 2007), such as potato skins (PS) (R. F. Magnago, et al., 2020) and yam skins (YS) (P. Fajfrlíková, et al., 2020). PS is environmentally friendly carbon (G. Z. Kyzas, et al., 2015). Briquettes made from PS have a high density and resistance to compression (R. F. Magnago, et al., 2020), while yam peels are an example of biomass with possible further use (P. Fajfrlíková, et al., 2020). Thus, YS can be used as the main ingredient in briquettes. Therefore, based on these facts (A. Amaya, et al., 2007, R. F. Magnago, et al., 2020, P. Fajfrlíková, et al., 2020 \& G. Z. Kyzas, et al., 2015) potato skin (PS) and yam skins (YS) carbon can be used as briquettes and produce good quality briquettes.

Rice is one of the main foods in Indonesia (A. Widyanti, et al., 2014). According to the Food and Agriculture Organization (FAO), rice waste is recorded as having a large amount of 
methane gas as a cause of environmental pollution (R. Guan, et al., 2018). One of the management of rice waste is as an adhesive for briquettes. Therefore, in this study, rice was used as the adhesive.

The briquettes are made with a mixture of PS and YS with rice waste as an adhesive is still rare. Therefore, this study is to utilize waste potato skins (PS) and yam skins (YS) in the production of briquettes with rice waste as a binder. Furthermore, the characteristics of briquettes were tested based on compressed density, relaxed density, relaxation ratio, percentage of moisture content, burning rate, percentage of water resistance index, percentage of durability index, and specific fuel consumption tests. Research on the comparison of rice waste adhesive on briquettes of potato skins and yam skins showed a significant effect. This research is expected to convey information regarding how to use carbon waste from potato skins (PS), yam skins (YS), and rice as briquettes and convey the effect of rice adhesive ratio on briquettes.

\section{MATERIALS AND METHODS}

1. Briquettes samples preparation

The research method used is experimental. The main ingredients used in this study were PS and YS with a ratio of 1:1. PS and YS were obtained from leftovers from sellers of processed potato and yam, and rice waste obtained from leftovers in homes and restaurants. The apparatus used in this research were oven, digital scale, oven thermometer, and $3 \times 2 \mathrm{~cm}$ briquette mold.

Figure 1 presents the steps for making briquettes. The briquettes were made by drying PS and YS. After that, the material was carbonized at $250^{\circ} \mathrm{C}$ for 3 hours. The carbonized material was saw-milled and separated by particles size of $250 \mu \mathrm{m}$. Then, the process of mixing the raw material used PS and YS (with a ratio of 1:1) and adhesive (composition ratios of 10, 20, 30, 40, and 50\%) under a pressure of $5.66 \mathrm{~Pa}$. After that, the prepared mold was dried under 
the sunlight and put in an oven with a temperature of $303-333 \mathrm{~K}$.

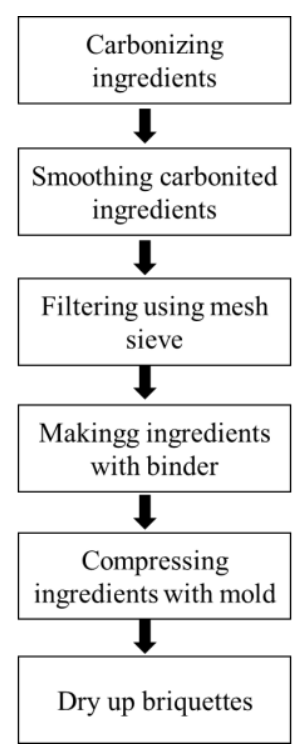

Figure 1 Briquettes making mechanism

2. Briquettes Characteristics Test

Several tests were done:

(1) Compressed density (CD) is the density value immediately after the briquette is removed from the mold (E. Aransiola, et al., 2019)

(2) Relaxed density (RD) can be interpreted as the density of briquettes in a stable mass and volume state.

(3) Relaxation Ratio (RR) is the ratio compressed density and relaxed density.

(4) Percentage of moisture content. The moisture content of briquettes is calculated after the briquettes are removed from the mold until they reach a constant mass after dry, according to European Standard EN 13183-1 (2002)

(5) Percentage of durability index. Durability tests are carried out by dropping briquettes which have been placed in an airtight plastic above a height of 2 meters onto a solid, hard surface (K. Abdullah, et al., 2016)

(6) Percentage of water-resistant index (PWRI) analysis was carried out by immersing the briquettes in water with a temperature of $27^{\circ} \mathrm{C}$ for $30 \mathrm{~s}$ (R. M. Davies, et al., 2013) 
(7) Burning rate (BR) is performed to measure the burning rate of briquettes

(8) Specific fuel consumption (SFC) shows the comparison mass of burning briquette with the amount of water that is boiled.

(9) The puncture test is a mechanical test to measure the strength of the briquette. In this study, the puncute test was carried out by testing five variations of briquettes using the Shore Durometer instrument (Shore A Hardness, In size, China).

(10) The hardness test is a mechanical test for material properties used in structural analysis and material development. In this study, hardness testing was carried out by testing five variations of sagon crackers using a Screw Stand Test Instrument (Mode I ALX-J, China) equipped with a measuring instrument (Digital Force Meter (Model HP500, Serial). No. H5001909262)).

\section{RESULTS AND DISCUSSION}

\section{Density}

Figure 2 presents the effect of variations in the ratio of rice adhesive on briquettes from PS and YS on the compressed density (CD) value. The highest $C D$ value was obtained at an adhesive ratio of $40 \%$, namely 0.69 , and the lowest $\mathrm{CD}$ value was obtained at an adhesive ratio of $10 \%$, namely 0.63 . The value increases with the increase in the amount of adhesive from 10 to $40 \%$ (E. Aransiola, et al., (2019) because of the variation in the amount of adhesive used affects the density of the compressed briquette (K. Abdullah, et al., 2016). But when the ratio of $50 \% \mathrm{CD}$ value decreases, this is due to the increase in briquette volume due to expansion that occurs after it is removed from the mold (E. Aransiola, et al., 2019). This is in line with previous research (R. M. Davies, et al., 2013 \& R. M. Davies, et al., 2013) that the adhesive mixing ratio has a significant effect on the compressed density of briquettes.

Figure 2 presents the effect of variation in the ratio of rice adhesive on briquettes from PS and YS on relaxed density (RD) value. The results showed that the highest RD value was found in 
$10 \%$ of adhesive with a result of 0.475 while the lowest value was obtained from $50 \%$ of adhesive with a result of 0.418 . The addition of adhesive to the briquettes causes the water content in the briquettes to increase which results in decreasing the value RD. This is due to the consolidation of the briquette adhesive mixture and a decrease in elastic recovery during the relaxation of the formed briquettes. The higher the value of the relax density, the higher the stability of the briquettes (E. Aransiola, et al., (2019). This is in line with the results of other studies, that the density of briquettes depends on the type and amount of binder (M. E. Arewa, et al., 2016).

Figure 2 shows the Relaxation Ratio (RR) or the ratio between the briquette density immediately after being removed from the mold with the briquette density after reaching a constant weight. This study showed that PS and YS briquettes with adhesive content of 50\% had the highest relaxation ratio levels and briquettes with $10 \%$ of adhesive content had the lowest levels of relaxation ratio. This happens because the addition of adhesive to the briquettes increases the water content in the briquettes which results in a decrease in the value of relaxed density and an increase in the value of the relaxation ratio comparable to previous studies. The results of this study are in line that the lower the relaxation ratio value, the higher the stability of the briquettes (E. Aransiola, et al., (2019).

2. Percentage of moisture content

Figure 2 presents the effect of variations in the ratio of rice adhesive on briquettes from PS and YS on the value of Percentage of Moisture Content (PMC). PMC in this study showed a value between $25-38 \%$. PS and YS briquettes with $50 \%$ of adhesive had high yields while the lowest values were found in briquettes with $10 \%$ of adhesive. Figure 2 shows that the higher the adhesive composition the higher the PMC value. This is because the adhesive containing starch will affect the water binding. Adhesives with water solvents will also increase the moisture content of the briquettes (K. Abdullah, et al., 2016). The addition of adhesive causes PMC levels to be higher in line with research (Elfiano, et al. 2014). The resulting PMC value 
is not good, because previous research states (E. Elfiano, et al., 2014) that the moisture content optimal for a briquette is $12-20 \%$.

3. Percentage of water resistance index

Figure 2 presents the percentage of water resistance index absorbed by briquettes from PS and YS. Of the five variations in the composition of rice adhesive on the briquettes from PS and YS. The average moisture content of the $30 \%$ composition and the $50 \%$ moisture content has a PWRI below $100 \%$, namely 76 and $95 \%$, respectively. While the highest water content is owned by briquettes at $40 \%$ of adhesive composition with a value of $132 \%$. The starch content in rice can bind water content, but the starch content when the rice dries due to heating reduces the absorption of water (Han, et al., 2001). The increased PWRI value is the result of improved bonding between particles due to better flow or the binding properties component at higher temperatures (J. Orisaleye, et al., 2019). While the PWRI value decreases due to the wider cavity between particles that limit the bonds between particles, this ultimately reduces the PWRI of the briquettes (J. Orisaleye, et al., 2019). These results are consistent with previous research,that the use of binders affects the water-resistance of briquettes (A. Özyuğuran, et al., 2017).

4. Percentage of durability index

Figure 2 presents the resistance value of briquettes from PS and YS. This durability test is used to determine the strength or resistance of the briquette to impact. The results showed that the highest PDI value was obtained from briquettes with $20 \%$ of adhesive, namely $98.66 \%$, while the smallest PDI value was obtained from briquettes with $50 \%$ of adhesive namely $65 \%$. Increasing the amount of adhesive rice can reduce the resistance of the briquettes. This is because the low amylose content gives the rice maximum stickiness (F. P. Pangerang, et al., 2018). The higher the amylose content in rice adhesive, the less sticky properties of the rice will be, so that the resulting resistance is not optimal as shown using $30 \%-50 \%$ of adhesive in this study. This is in line with research (S. Suryaningsih, 2020) which explains that the PDI 
value in rice adhesive will decrease along with the increase in the amount of rice adhesive.

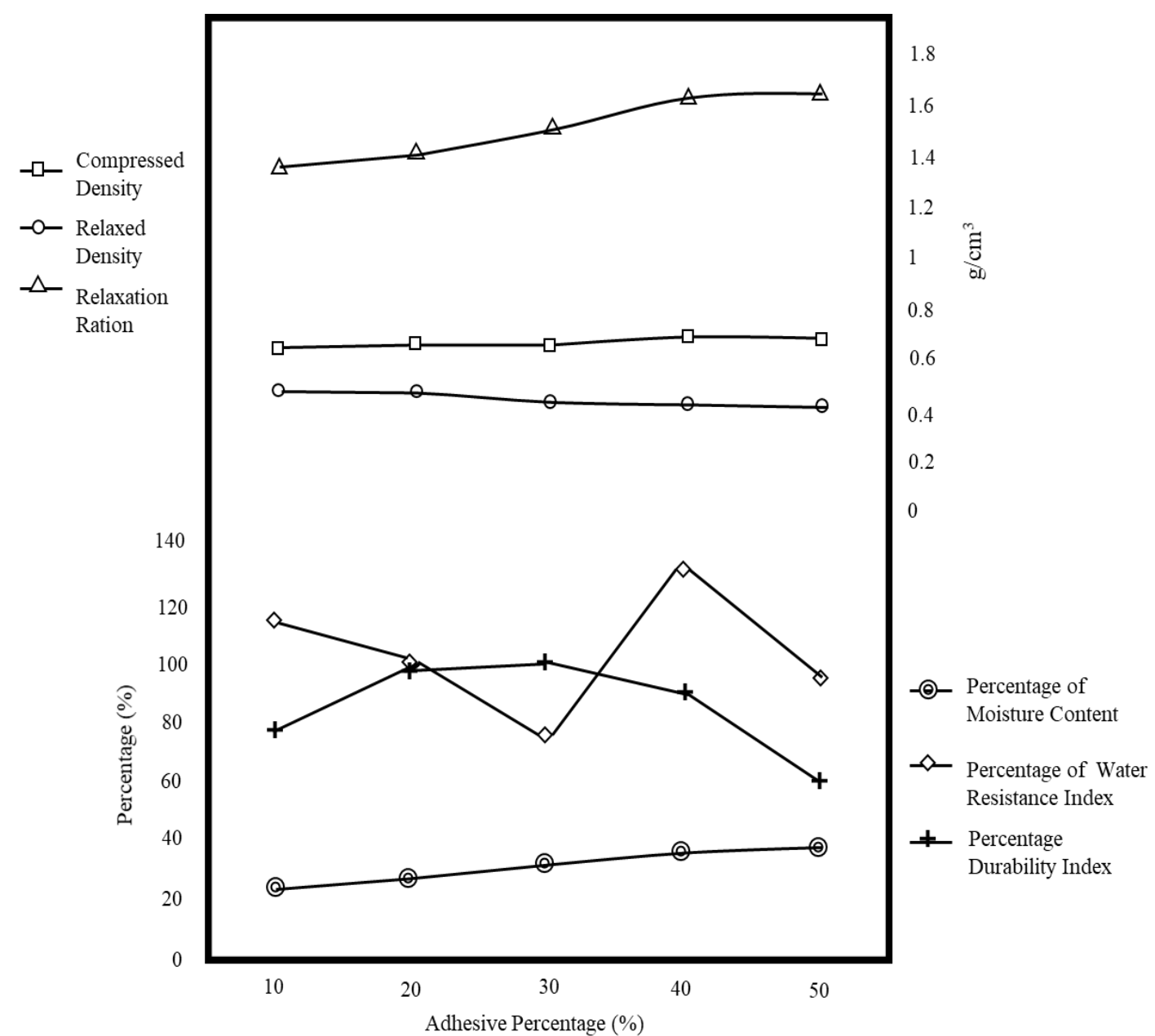

Figure 2 Graph of CD, RD, RR, PMC, PWRI, and PDI test results with variations in the composition of rice adhesives 10, 20, 30, 40, and 50\%. Example of figure

\section{Burning rate}

Figure 3 presents the burning rate test result with variations in the ratio of rice adhesive to briquettes from PS and YS. At 40 and 50\% of adhesive compositions, the average burning rate was low, and the two compositions were close at $0.3947 \mathrm{~g} / \mathrm{min}$ for $40 \%$ of adhesive composition and $0.3992 \mathrm{~g} / \mathrm{min}$ for $50 \%$ of adhesive composition. The highest average burning rate value is found in the adhesive composition of $10 \%$, which is $0.5654 \mathrm{~g} / \mathrm{min}$. In literature, it is said that briquette ash comes from clay, sand, and various other mineral substances. Increasing the composition of the adhesive causes the briquettes to become denser and 
reduces the air cavity in the briquettes, thus limiting mass and heat transfer during combustion (M. Thabuot, et al., 2015). Besides, the higher the ash in a briquette, the lower the quality of the briquette because it can reduce the calorific value of the briquettes (I. Zakari, et al., 2013). The binding of the main ingredients of the briquettes with adhesive inhibits the burning of the briquettes so that mass decreases when the adhesive composition increases (R. M. Davies, et al., 2013 \& R. M. Davies, et al., 2013). Therefore, the value of the briquette combustion rate decreases with the increasing adhesive composition (R. M. Davies, et al., 2013).

\section{Specific Fuel Consumption}

Figure 3 presents the variation in the ratio of rice adhesive on briquettes from PS and YS to the value of Specific Fuel Consumption (SFC). SFC is the relationship between the mass of the briquette burned with the mass of boiled water. The test results show that the graph decreases with the increasing percentage of adhesive. SFC The highest value is found in the adhesive with a percentage of $10 \%$, while the lowest value is found in the adhesive composition of 50\%. The greater the heating value, the slower the combustion rate and the lower the SFC value, this is because more mass of fuel is needed to boil water (O. A. Kuti, 2009). The more briquettes with the adhesive mixture, the faster the burning rate will be because when the briquette heat burns, heat is used to use up the water in the briquettes (T. Olugbade, et al., 2019). The low adhesive mixture also results in the high content of biomass used as the main ingredient for combustion which results in high SFC values. This is in line with research (O. A. Kuti, 2009). 


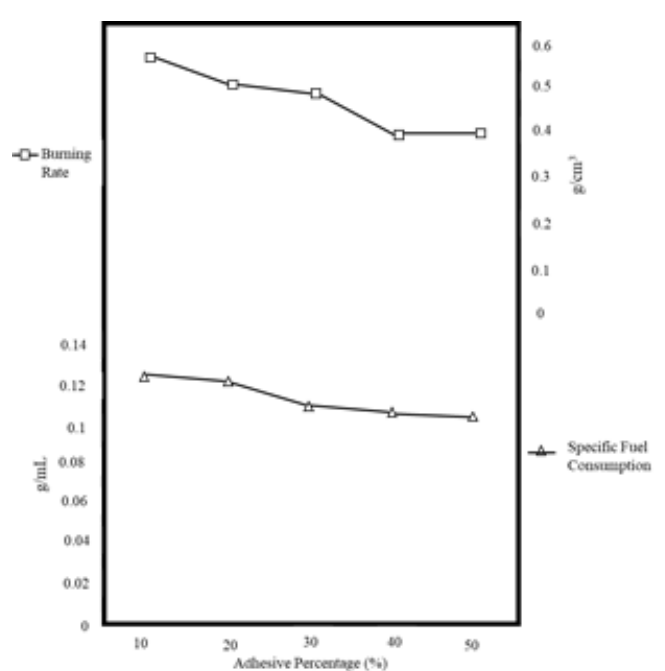

Figure 3 Graph of BR, and SFC with variations in the composition of rice adhesives 10, 20, 30,40 , and $50 \%$.

7. The puncture test

Table 1 shows the results of puncture observations on the characteristics of briquettes (PS) and (YS). Briquettes (PS) and (YS) in the 10\% adhesive variation have an average value of $50.60,20 \%$ adhesive variation has an average value of $73.40,30 \%$ adhesive variation has an average value of $17.20,40 \%$ adhesive variation has an average value of 42.50 an average of 24.50 and a $50 \%$ adhesive variation has an average value of 22.70 . The results showed that the highest puncture test value was owned by briquettes with a variation of $20 \%$, while the lowest value was owned by briquettes with a variation of $30 \%$ adhesive. This is because the low amylose content gives the rice maximum stickiness (F. P. Pangerang, 2018), as shown in the use of $30-50 \%$ adhesive. The possibility of the emergence of fluctuating data can be triggered by the breakdown of the briquette due to the lack of density on the briquette, or the formation of an ash layer on its surface (J. M. Tabarés, 2006).

Table 1 Puncture test results with variations of rice adhesives

\begin{tabular}{|l|l|l|l|l|l|}
\hline Ratio & $\mathbf{1 0 \%}$ & $\mathbf{2 0 \%}$ & $\mathbf{3 0 \%}$ & $\mathbf{4 0 \%}$ & $\mathbf{5 0 \%}$ \\
\hline Average puncture test & $\mathbf{5 0 . 6 0}$ & $\mathbf{7 3 . 4 0}$ & $\mathbf{1 7 . 2 0}$ & $\mathbf{4 2 . 5 0}$ & $\mathbf{2 2 . 7 0}$ \\
\hline
\end{tabular}


8. The hardness test

Figure 4 shows the mechanical test results of all variations of briquettes (PS) and (YS). The highest value is indicated by the adhesive ratio of $10 \%$, while the lowest value is obtained by the adhesive of $30 \%$. The higher the density value of a product, the higher the value of the resulting mechanical strength. However, the results obtained from this study do not agree with this statement. High density values are obtained for $40 \%$ adhesive. The possibility of the emergence of fluctuating data can be triggered by the breakdown of the briquette due to the lack of density on the briquette, or the formation of an ash layer on its surface (Tabarés, et al., 2006). In addition, the value of mechanical strength is strongly influenced by the type of material, particle size, type of adhesive, pressure, and briquette density.

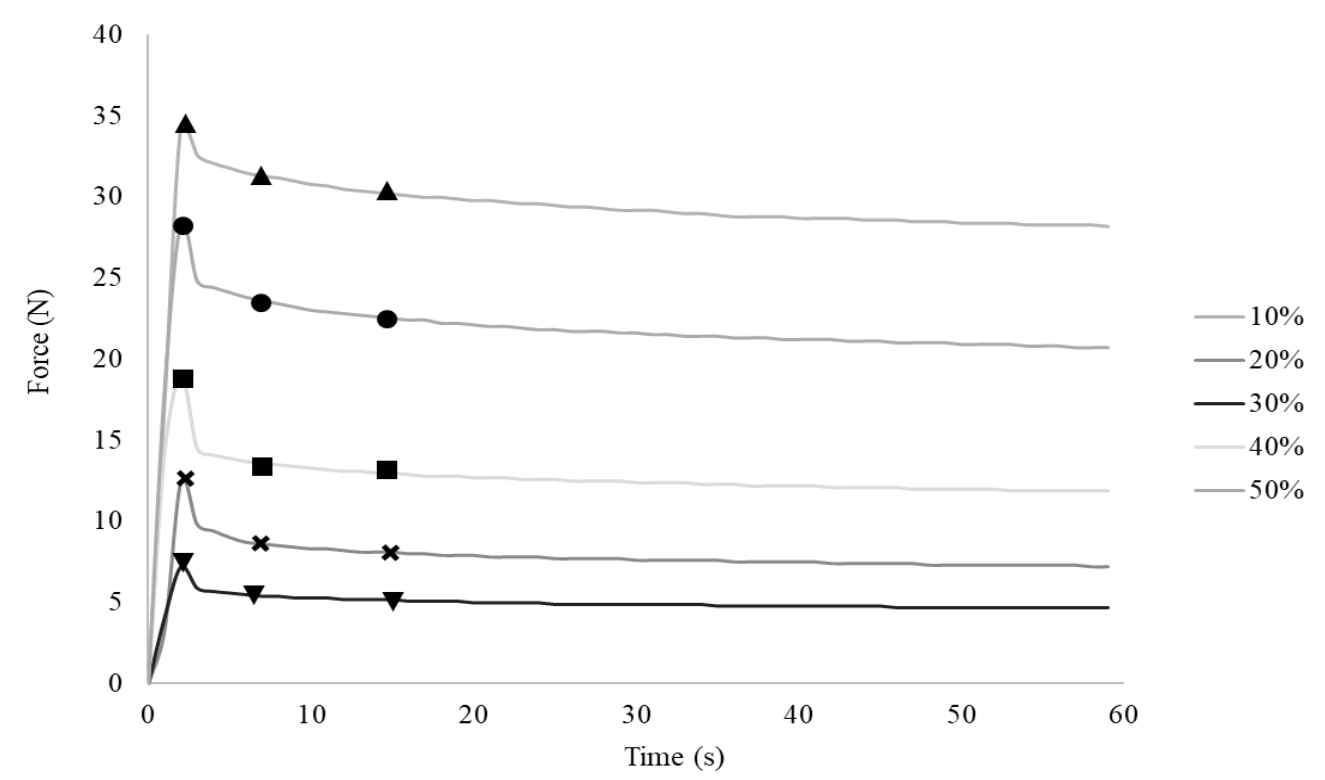

Figure 4 The hardness test results with variations in the composition of rice adhesives. 


\section{CONCLUSION}

In this study, the use of rice waste as a briquette adhesive and the effect of the ratio of rice adhesive to briquettes from PS and YS were analysed. The characteristic briquettes were analysed using several parameters. The results of the relaxed density, relaxation ratio, moisture content, burning rate, specific fuel consumption, and the hardness test showed that good quality briquettes were obtained from briquettes with $10 \%$ of adhesive. The percentage test for the durability index, briquettes with $30 \%$ adhesive have good resistance. Experiments of compressed density and percentage of water resistance index showed that good briquettes are found in briquettes with a concentration of $40 \%$. The results of the puncture test and hardness test, briquettes with $10 \%$ adhesive have good value too. The results of this study indicate that the best briquettes from PS and YS are obtained from briquettes with adhesive by $10 \%$. Based on the current results obtained, the waste carbon of potato skins (PS) and sweet potato skins (YS) with rice adhesive can be used as briquettes with good characteristics. The use of rice adhesive can produce briquettes with good characteristics, if the correct amount is carefully selected.

\section{REFERENCES}

Raju, C. A., Jyothi, K. R., Satya, M., \& Praveena, U. (2014). Studies on development of fuel briquettes for household and industrial purpose. International Journal of research in Engineering and Technology, 3(2), 54-63.

Moelyaningrum, A. D., Molassy, H. D., \& Setyowati, I. K. (2019). The formulation Robusta coffee bark Jember Indonesia for charcoal Briquettes as alternative energy: The comparison organic starch adhesive and anorganic adhesive. Journal of Physics: Conference Series, 1363(1), 012091.

Abakr, Y. A., \& Abasaeed, A. E. (2006). Experimental evaluation of a conical-screw briquetting machine for the briquetting of carbonized cotton stalks in Sudan. Journal of 
engineering science and technology, 1(2), 212-220.

Yerizam, M., Faizal, M., Marsi, M., \& Novia, N. (2013). Characteristics of composite rice straw and coconut shell as biomass energy resources (Briquette)(Case study: Muara Telang Village, Banyuasin of South Sumatra). International Journal on Advanced Science Engineering Information Technology, 3(3), 42-48.

Rezania, S., Din, M. F. M., Kamaruddin, S. F., Taib, S. M., Singh, L., Yong, E. L., \& Dahalan, F. A. (2016). Evaluation of water hyacinth (Eichhornia crassipes) as a potential raw material source for briquette production. Energy, 111, 768-773.

Saptoadi, H., Syamsiro, M., \& Tambunan, B. H. (2007). Biomass Waste utilization from Cacao and Candle Nut shells as fuel briquettes. Jurnal Manusia \& Lingkungan (UGM), 14(3), 127-136.

Syafrudin, S., Zaman, B., Indriyani, I., Erga, A. S., \& Natalia, H. B. (2015). The Utilization of Bottom Ash Coal for Briquette Products by Adding Teak Leaves Charcoal, Coconut Shell Charcoal, and Rice Husk Charcoal. Waste Technology, 3(1), 14-21.

Amaya, A., Medero, N., Tancredi, N., Silva, H., \& Deiana, C. (2007). Activated carbon briquettes from biomass materials. Bioresource Technology, 98(8), 1635-1641.

Magnago, R. F., Costa, S. C., de Assuncao Ezirio, M. J., de Godoy Saciloto, V., Parma, G. O. C., Gasparotto, E. S., ... \& Barcelos, R. L. (2020). Briquettes of citrus peel and rice husk. Journal of Cleaner Production, 276, 123820.

Fajfrlíková, P., Brunerová, A., \& Roubík, H. (2020). Analyses of Waste Treatment in Rural Areas of East Java with the Possibility of Low-Pressure Briquetting Press Application. Sustainability, 12(19), 8153.

Kyzas, G. Z., \& Deliyanni, E. A. (2015). Modified activated carbons from potato peels as green environmental-friendly adsorbents for the treatment of pharmaceutical effluents. Chemical Engineering Research and Design, 97, 135-144.

Guan, R., Li, X., Wachemo, A. C., Yuan, H., Liu, Y., Zou, D., ... \& Gu, J. (2018). 
Enhancing anaerobic digestion performance and degradation of lignocellulosic components of rice straw by combined biological and chemical pretreatment. Science of the Total Environment, 637, 9-17.

Widyanti, A., Sunaryo, I., \& Kumalasari, A. D. (2014). Reducing the dependency on rice as staple food in Indonesia-A behavior intervention approach. Journal of ISSAAS, 20(1), 93-103.

Aransiola, E. F., Oyewusi, T. F., Osunbitan, J. A., \& Ogunjimi, L. A. O. (2019). Effect of binder type, binder concentration and compacting pressure on some physical properties of carbonized corn cob briquette. Energy Reports, 5, 909-918.

Abdullah, K., Zulfa, Z., \& Jyoti, M. D. (2016). Pengaruh Penambahan Tandan Kosong Kelapa Sawit terhadap Kualitas Briket Berbahan Utama Limbah Kulit Singkong. Jurnal Dinamika Penelitian Industri, 27(1), 49-58.

Arewa, M. E., Daniel, I. C., \& Kuye, A. (2016). Characterisation and comparison of rice husk briquettes with cassava peels and cassava starch as binders. Biofuels, 7(6), 671-675.

Davies, R. M., \& Abolude, D. S. (2013). Ignition and burning rate of water hyacinth briquettes. Journal of Scientific Research and Reports, 111-120.

Elfiano, E., Subekti, P., \& Sadil, A. (2014). Analisa proksimat dan nilai kalor pada briket bioarang limbah ampas tebu dan arang kayu. Jurnal Aptek, 6(1), 57-64.

Han, X. Z., \& Hamaker, B. R. (2001). Amylopectin fine structure and rice starch paste breakdown. Journal of Cereal Science, 34(3), 279-284.

Kuti, O. A. (2009). Performance of composite sawdust briquette fuel in a biomass stove under simulated condition. AU JT, 12(4), 284-288.

Olugbade, T., Ojo, O., \& Mohammed, T. (2019). Influence of binders on combustion properties of biomass briquettes: a recent review. BioEnergy Research, 12(2), 241-259.

Orisaleye, J. I., Jekayinfa, S. O., Pecenka, R., \& Onifade, T. B. (2019). Effect of densification variables on water resistance of corn cob briquettes. 
Özyuğuran, A., Acma, H. H., \& Dahiloğlu, E. (2017). Production of fuel briquettes from rice husk-lignite blends. Environmental Progress and Sustainable Energy, 36(3), 742-748.

Pangerang, F. P., \& Rusyanti, N. (2018). Karakteristik dan mutu beras lokal kabupaten bulungan kalimantan utara. Canrea Journal: Food Technology, Nutritions, and Culinary Journal, 107-117.

Suryaningsih, S. (2020). Pengaruh tekanan pembriketan terhadap karakteristik mekanik dan karakteristik pembakaran pada briket campuran sekam padi dan bonggol jagung. JIIF (Jurnal Ilmu dan Inovasi Fisika), 4(1), 23-28.

Tabarés, J. M., Granada, E., Moran, J., Porteiro, J., Murillo, S., \& González, L. L. (2006). Combustion behavior of Spanish lignocellulosic briquettes. Energy Sources, Part A, 28(6), 501-515.

Thabuot, M., Pagketanang, T., Panyacharoen, K., Mongkut, P., \& Wongwicha, P. (2015). Effect of applied pressure and binder proportion on the fuel properties of holey biobriquettes. Energy Procedia, 79, 890-895.

Zakari, I. Y., Ismaila, A., Sadiq, U., \& Nasiru, R. (2013). Investigation on the effects of addition of binder and particle size on the high calorific value of solid biofuel briquettes. Journal of Natural Sciences Research, 3(12), 30-34. 